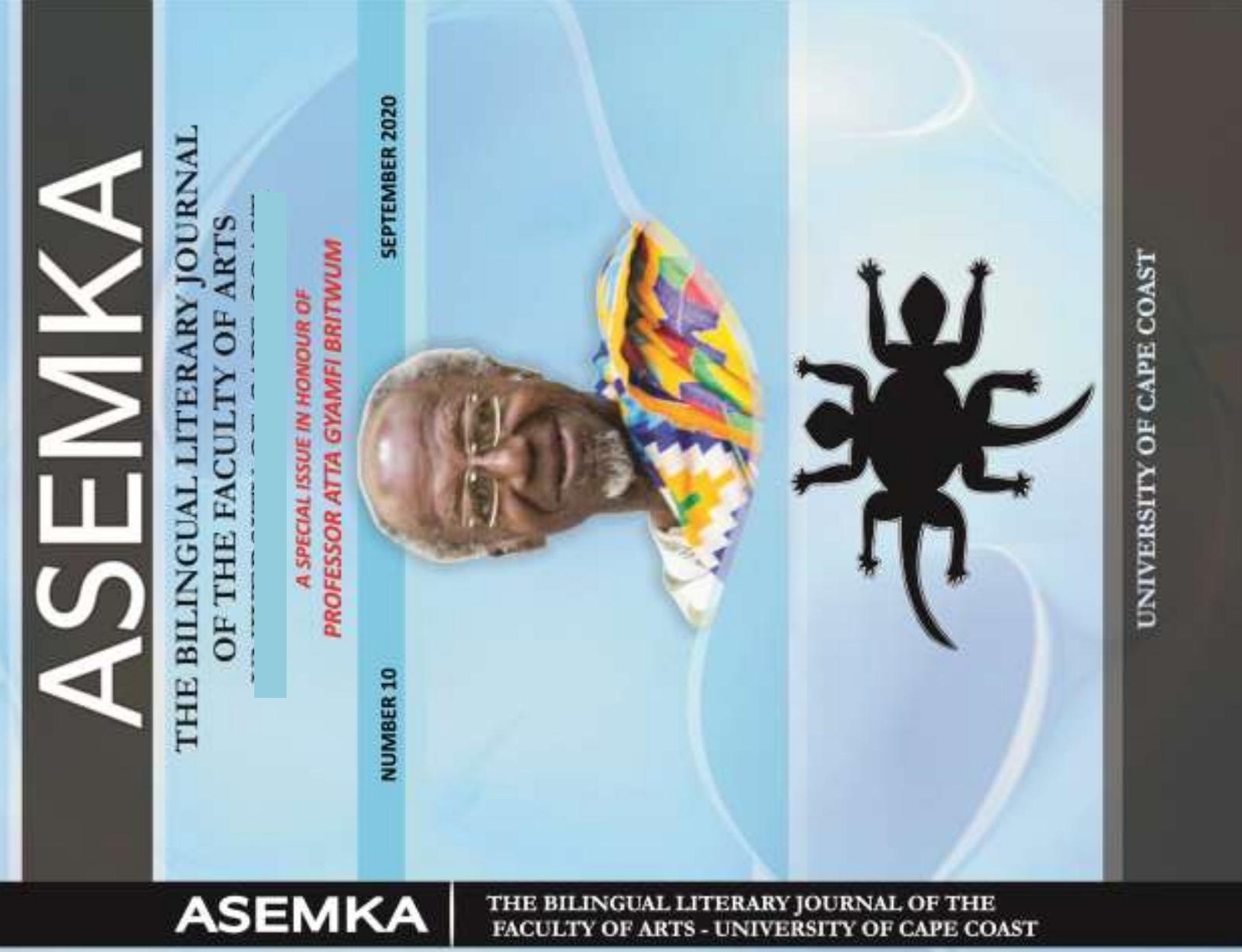





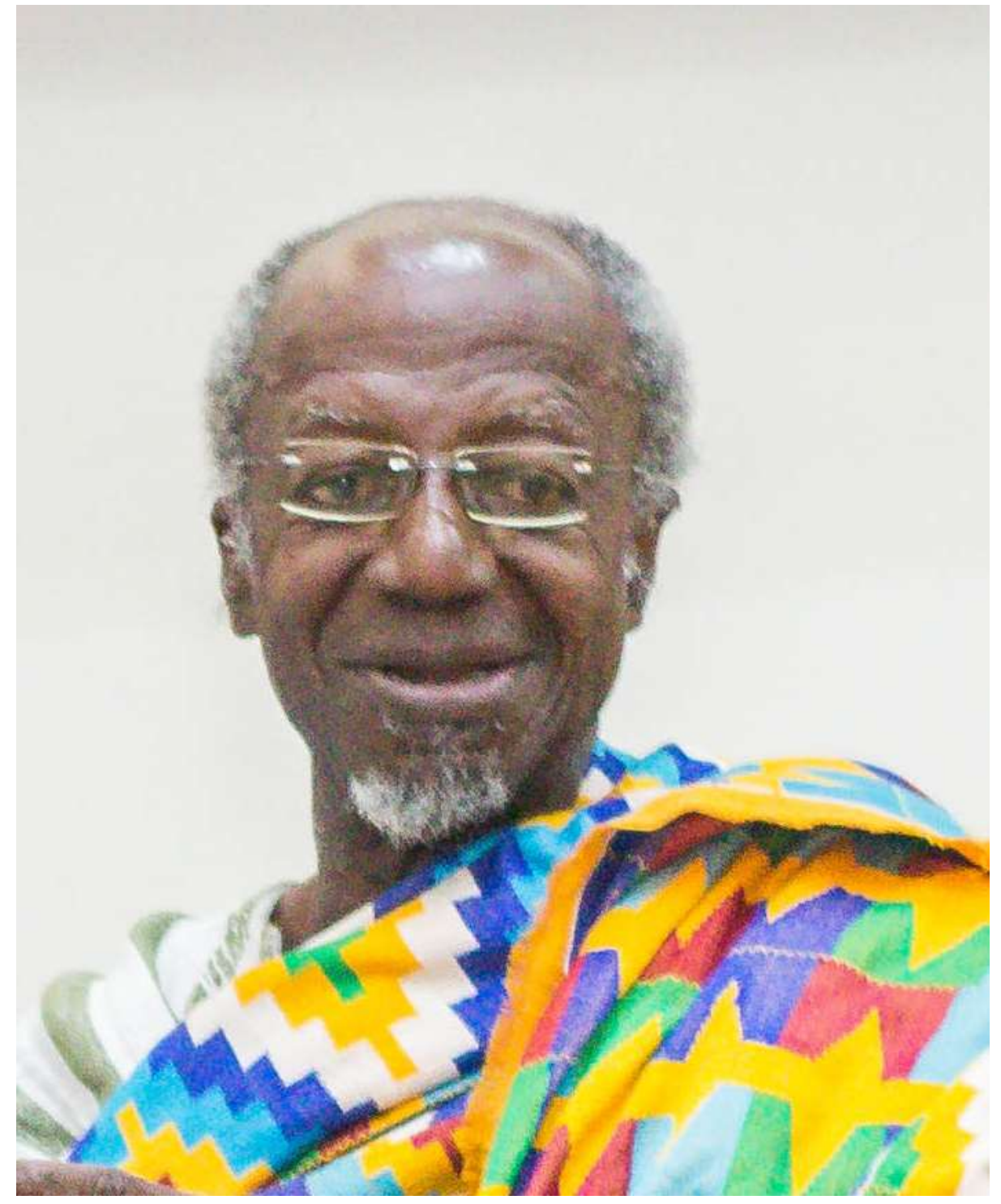
PROFESSOR ATTA GYAMFI BRITWUM 


\section{THE BILINGUAL LITERARY JOURNAL OF THE FACULTY OF ARTS UNIVERSITY OF CAPE COAST}

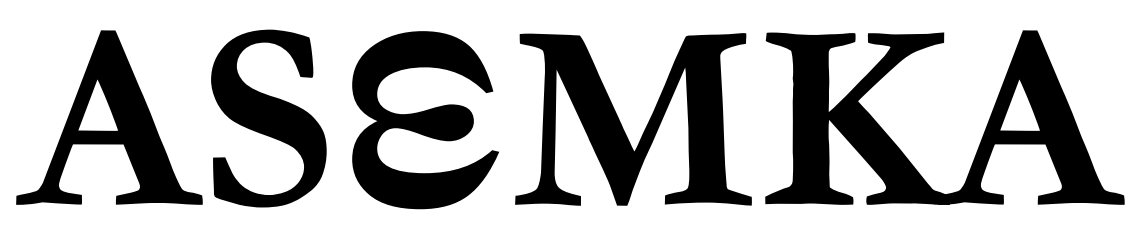

NUMBER 10

SEPTEMBER 2020

\section{EDITORIAL COMMITTEE}

Editor-in-Chief: $\quad$ Prof. Samuel Awuah-Nyamekye (Ph.D.)

Editor: $\quad$ Prof. Mawuloe Koffi Kodah (Ph.D.)

Associate Editors: Dr. Samuel Kwesi Nkansah

Dr. Mrs. Theresa Addai Munumkum

Dr. Isaac Mwinlaaru

Business Editor: Rev. Sr. Dr. Matilda Alice Nsiah

\section{EDITORIAL STAFF}

Mr. Stephen Owusu-Amoh

Mr. Isaac Kweku Grantson

\section{EDITORIAL ADVISORS}

Prof. Kwadwo Opoku-Agyemang, University of Cape Coast.

Prof. Joseph B. A. Afful, University of Cape Coast.

Prof. Raymond N. Osei, University of Cape Coast.

Prof. Richard V. Cudjoe, University of Cape Coast. 
Prof. Victor K Yankah, University of Cape Coast.

Dr. Mousa Traore, University of Cape Coast.

\section{ACKNOWLEDGEMENTS}

We acknowledge the contribution of the underlisted members of the Department of French who did preliminary editorial work on the papers:

Dr. Anthony Y.M. De-Souza (Chairman)

Prof. Raymond N. Osei

Prof. Mawuloe K. Kodah

Dr. Sylvester P. Krakue

Mr. Ofosu Addo-Danquah

Mr. Micheal Donkoh (Secretary)

\section{SUBSCRIPTION}

Assmka is published twice in the Academic year by the Faculty of Arts, University of Cape Coast. The annual out-of-Ghana subscription rate, including air-postage, is US\$29 for individuals, and US\$ 59 for institutions and libraries. Single issue rate for individuals is US\$18. Claims for copies not received must be made within three (3) months following an issue's publication. Correspondence should be addressed to:

The Editor, Assmka

Department of French

Faculty of Arts

College of Humanities and Legal Studies

University of Cape Coast

Cape Coast

Ghana, West Africa

Email: asemkajournal@ucc.edu.gh

\section{ADVERTISING}

Advertising rate, size specifications and related information are available upon request. Please, contact the General Editor for more information.

\section{SUBMISSIONS}

Ascmka is an internationally-refereed journal of the Humanities. It publishes scholarly and imaginative articles in Literature, Language, and Culture generally, including, Orature, Film, Theatre, Music and Art. Essays, Interviews, Book Reviews, Poetry, Short Prose Fiction and Drama are welcome. Submitted manuscripts, in English and French, must be prepared in accordance with the most recent of APA or MLA style manual, where 
applicable. The author's identity and address may appear only on the coverpage and nowhere else within the submitted manuscript. All manuscripts should be submitted electronically through:

asemkajournal@ucc.edu.gh

Manuscript will be duly acknowledged within two (2) months of receiving them. Individuals whose works are accepted for publication may provide Assmka with a brief bio-data. The Editors cannot be held liable for lost or damaged manuscripts. Material published by Assmka does not necessarily represent the views of the Journal's Editors, Staff, Financial Supporters or the University of Cape Coast and its affiliates. These parties disavow any legal responsibility related to all submitted material.

\section{BACK ISSUES}

Back issues of Ascmka that are in stock may be ordered from the Editor at US\$20 per copy.

\section{GRANT SUPPORT}

Assmka is funded through grants from the Office of the Dean, Faculty of Arts; the Publications' Board; and the Office of the Vice-Chancellor, University of Cape Coast, Cape Coast, Ghana.

No part of this Journal may be reproduced, stored in a retrieval system, or transmitted in any manner whatsoever without express permission from the Editors, except in the case of brief quotations embodied in critical Articles and Reviews.

Copyright (C2020 by The Editors and The Faculty of Arts, University of Cape Coast. The cover and page design elements were inspired by the Adinkra symbols of Ghana. 


\section{DEDICATION \\ PROFESSOR ATTA GYAMFI BRITWUM}

Professor Britwum is a man of many parts. He is as much at home with Marxist Economic Theory and Feminist Sociological Thoughts, as he is with French and Francophone Literatures. He is a great teacher and Administrator of international acclaim. The Editors dedicate this special issue of Ascmka to his honour. 


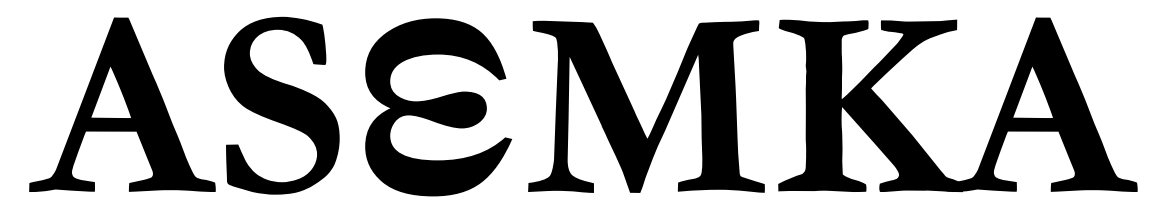

NUMBER 10

SEPTEMBER 2020 


\section{CONTENTS}

$\begin{array}{llll}\text { Editorial Committee } & \sim & \sim & \sim i i \\ \text { Editorial Staff } & \sim & \sim & \sim i i \\ \text { Editorial Advisors } & \sim & \sim & \sim i i \\ \text { Acknowledgements } & \sim & \sim & \sim i i i \\ \text { Subscription } & \sim & \sim & \sim i i i \\ \text { Advertising } & \sim & \sim & \sim i i i \\ \text { Submissions } & \sim & \sim & \sim i i i \\ \text { Back Issues } & \sim & \sim & \sim i v \\ \text { Grant Support } & \sim & \sim & \sim i v \\ \text { Dedication } \sim & \sim & \sim & \sim \\ \text { Foreword } \sim & \sim & \sim & \sim x \\ \text { Assmka: Editorial } & \sim & \sim & x i-x v i i\end{array}$

Articles

First Section - French

Britwum, A. G.

Insuffisances Théoriques Des Damnés De La Terre De

Frantz Fanon

$\sim$

$\sim 2-15$

Kodah, M. K.

Disculpation de Dieu dans le malheur des hommes:

Une lecture critique de Gouverneurs de la rosée de

Jacques Roumain $\sim \sim \sim 16-31$

Addo-Danquah, $O$.

Le récit de pensées: Une analyse comparative de Vol de nuit d'Antoine de Saint-Exupéry et La Condition humaine d'André Malraux

Kodah, M. K. \& Togoh, A. A. X.

Réactions des femmes face au conflit de genre dans C'est le soleil qui m'a brûlée et Tu t'appelleras Tanga de Calixthe Beyala

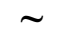

$\sim$

$\sim \quad 45-59$ 
Kudi, M. D.

La Littérature francophone face aux médias de télécommunication : Une nouvelle dynamique de la création romanesque, le cas de L'Énigme de retour et Tout bouge autour de moi de Dany Laferrière $\sim \quad$ 60-72

Gli, $M$.

Les faces du bonheur dans Vol de nuit d'Antoine de Saint-Exupéry $\sim \sim 73-85$

Krakue, S. P.

Christ haïtien : Gouverneurs de la rosée et La Bible $\sim 86-93$

Afari, E. S. K. \& Yegblemenawo, C. A. A.

Apports de la télésérie à l'amélioration de la compétence d'expression orale du FLE à l'école normale $\sim 94-116$

Bationo, J.-Cl.

Didactique de la littérature et littérature didactique:

l'exemple de la littérature africaine francophone en classe de langues étrangères au Burkina Faso

Second Section - English

Krakue, S. P.

Quod erat demonstrandum: A comparative study of narrative technique in Ama Ata Aidoo's Changes and Albert Camus'

Les justes (The Just Ones) 〜 $\sim$ $133-141$

Adjandeh, E. A.

Analysis of Wole Soyinka's Trials of Brother Jero in Relation to Ghanaian Religious Discourse $\sim 143-153$

Sam, C. A.

Decolonizing the Postcolony: Of Men, Spatial Politics and the New Nation in WA Thiongo's Wizard of the Crow.

Kambou, M. K. \& Traore, S. A.

Manipulation and the popular uprising in Burkina Faso in 2014. $\sim \quad \sim 172-189$ 
De-Soura, A. Y.M.

Test-taking Strategies of University of Cape Coast Students of

French as a Foreign Language: a Case Study $\sim 191-216$

Kambou, M. K. \& Soma, L.

Local Culture and EFL Vocabulary Learning $\sim \quad 217-238$

Kabore, A. \& Nazortin, C.

Critical Analysis of the Place and Importance of Literature in the Teaching / Learning of English and in School Leaving Certificate Examination in Burkina Faso from 1985 to 2018

Malgoubri, I., Sawadogo, M. \& Kambou, M. K.

Digital Audio-visuals Aids and Listening in English as a

Foreign Language Classrooms

Osei, R. N. \& Inusah, $H$.

A Critique of the Images of Heaven in the Scriptures of the

Abrahamic Religions: An Existentialist Perspective $\sim$ 270- 282

Negedu, A. K.

Lexical Gaps and Ideological Shift in the Translation of

Chinua Achebe's Things Fall Apart as "Le Monde

S'effondre" in French $\sim \sim 283-297$

Talburt, $T$.

Political Transformation and Development in Africa:

Lessons from Achebe's Things Fall Apart

$\sim 298-313$ 


\section{FORWORD}

All the papers in this Volume were presented at a three-day Conference in honour of Professor Atta Gyamfi Britwum who turns eighty years in March 2021. Most of those years he spent at University of Cape Coast, having cut his teeth as a young lecturer in French language and Literature-in-French in 1974. After many years of an illustrious career in teaching, publication and extension, he bowed out at age seventy, but he didn't get the well-deserved rest he was entitled to; he continues to support his Department and the University as a whole. Today, Professor Britwum's name is associated with high standards of professionalism which earned him the nickname 'L'oracle'. Indeed, it is impossible to find another name universally acknowledged as embodying the excellence in French education offered at the Department of French, University of Cape Coast.

The decision to honour Professor Britwum couldn't have been taken at a more appropriate time. It was planned to coincide with the fiftieth anniversary of the publication of the Beautyful ones are not yet Born, Ayi Kwei Armah's first novel. Britwum never grew tired of reading, teaching and examining it. Such was his respect for Armah's craft. So, the three-day Conference was as much a celebration of Armah's contribution to the shaping of the African novel as it was a tribute to Professor Britwum's work as a teacher of literature of immense influence.

One only has to look at the titles of the papers published in this Volume to get an idea of how deep his influence runs at UCC and beyond. Most of the contributors once upon a time sat at the master's feet, but are now scholars in their own right keeping the flame of French scholarship burning bright (George Cooper: "Polished in a high degree, as each froggie ought to be/Now they sit on other logs, teaching other little frogs.") A good number of the papers are on Literature, nonetheless not limited to Armah's works. No Surprise there. Nevertheless, there are Language papers there too. No surprise here either, for the man to whose honour the Volume is dedicated is equally at home in both Language and Literature

\section{Lawrence $K$. Owusu-Ansah,}

Department of English, UCC.

A Disciple 


\section{$A S E M K A:$ EDITORIAL}

This Special Edition of $A S E M K A$, a bilingual literary journal of the University of Cape Coast, is published in honour of Prof. Atta Gyamfi Britwum, a revered Associate Professor of Francophone African Literature and Civilisation in the Department of French, U.C.C. It contains twenty (20) papers centred on diverse areas of teaching and research in the Humanities and on the theme of the Conference - Literature and the Humanities in the 21 Century: Interdisciplinary Perspectives - held in his honour by the Department of French, University of Cape Coast, Ghana, $13^{\text {th }}-15^{\text {th }}$ Mars, 2019. To reflect Prof. Britwum's area of research interest, the essays are arranged in two sections according to his dominant medium of instruction (French language) and speciality (Literature and Civilisation), followed by those in English language. The first section consists of a set of nine (9) essays in French spanning between themes in Literature and Language. The second section is made up of a set of eleven (11) essays in English which examine issues in literary studies, Language and Didactics, ICT and French Education, Philosophy, and Translation, among others. This special arrangement is however representative of the bilingual nature of the Journal.

\section{First Section}

Britwum, A. G.'s paper titled, “Insuffisances Théoriques Des Damnés De La Terre De Frantz Fanon", presents the Fanonian perspective as a complement to the African nationalism that informed anticolonial struggles. The study posits that African nationalism, populist in nature, for failing to target the capitalist economic base, which defines colonialism, ended up strengthening it. It concludes that Fanon's anticolonialist perspective, despite its overt radicalism, is not designed to allow a "bottom-to-top change" in colonial / capitalist society.

Kodah, M. K.'s paper titled, "Disculpation de Dieu dans le malheur des hommes: Une lecture critique de Gouverneurs de la rosée de Jacques Roumain", puts into question the responsibility of God in the suffering of men on earth and the capacity of man to make and unmake himself. The study aims at absolving God of the guilt of the miseries of men, and also questioning the atheistic or anti-religion denunciation of this narrative 
text since its publication. The study is accomplished through a critical reading and a thoughtful analysis of Jacques Roumain's Gouverneurs de la rosée within the analytical structure of literary studies and sociocriticism.

Addo-Danquah, O.'s paper, "Le récit de pensées : Une analyse comparative de Vol de nuit d'Antoine de Saint-Exupéry et La Condition humaine d'André Malraux", drawing inspirations from theorists such as Léon Edel (1961) and later Dorrit Cohn (1981), examines what Antoine de Saint-Exupéry's Vol de nuit by and André Malraux's La Condition bumaine respectively can offer on the side of representations of the interior life. The study is posited within the framework of narratological theories.

Kodah, M. K. \& Togoh Tchimavor, A. A. in "Réactions des femmes face au conflit de genre dans C'est le soleil qui m'a brûlée et Tu t'appelleras Tanga de Calixthe Beyala" examine the reactions of women to gender conflict in Calixthe Beyala's C'est le soleil qui m'a brulée and Tu t'appelleras Tanga. The study critically reflects on the various ways women in Beyala's C'est le soleil qui m'a brulée and Tu t'appelleras Tanga react to oppression and exploitation resulting from patriarchal domination. It therefore examines the sources and nature of this conflict, and how women react to it in the two novels. The study points to the fact that, much as conflict emanating from patriarchal oppression and male's domination in human societies is inimical to the rights of women, the methods used by the latter to free themselves from this state of being remain questionable, in that, these methods defy rational thinking and are also a kind of reversal oppression and domination which are equally unacceptable.

Kudi, M. D.’s paper, “La Littérature francophone face aux médias de télécommunication: Une nouvelle dynamique de la création romanesque, le cas de L'Énigme de retour et Tout bouge autour de moi de Dany Laferrière", seeks to examine how pertinent painting, photography, television, telephone etc. are to the production of the contemporary Francophone novel. The study focuses on L'Énigme de retour (2009) and Tout bouge autour de moi (2011). The analysis is based on the perspective of literary intermediality propounded by Jürgen E. Muller which is characterised by an interaction between telecommunication media and literary text. The study establishes through these selected novels that these media forms are not simply another form of expression in the novel but rather a lens through which the story is narrated. 
Gli, M.'s paper titled, "Les faces du bonheur dans Vol de nuit d'Antoine de Saint-Exupéry", analyses the faces of happiness in Antoine de Saint-Exupéry's Vol de Nuit. The study is conducted through thematic approach. This approach is complemented by Maslow's theory of human needs. The collection of data or the collection of information is purely documentary. The study therefore seeks to establish a link between individual happiness and collective happiness in Saint-Exupéry's selected narrative text.

Krakue, S. P.'s paper, “Christ haïtien : Gouverneurs de la rosée et La Bible", attempts to question Jacques Roumain's Gouverneurs de la rosée in order to elucidate the novelist's use of the biblical text in his creative activity. The study demonstrates that Jacques Roumain's narrative text turns out to borrow biblical ideas not only to develop his plot but also to design his main character.

Afari, E. S. K. \& Yegblemenawo, C. A. A. in “Apports de la télésérie à l'amélioration de la compétence d'expression orale du FLE à l'école normale." examine the impact examine the impact of the use of serial movies as teaching aid on oral expression of French language learners in Colleges of Education in Ghana with the aid of smartphones. The study discovers that the use of serial movies in teaching French boosts learners' performance in oral communication. It therefore recommends that serial movies could be used in teaching French language lessons in order to enhance the oral communication competencies among learners.

Bationo, J.-Cl.'s paper titled, "Didactique de la littérature et littérature didactique : l'exemple de la littérature africaine francophone en classe de langues étrangères au Burkina Faso", shows not only how to teach literature in language class but also how to use didactic literature to develop social skills among learners to reduce vandalism, school violence, negative stereotypes, misunderstandings of intercultural nature while cultivating social peace and living together in a context of internationalization, globalization and digital revolution. The paper focuses on francophone African Literature and posits that methodological approach used for the didactic transpositions of literary content is based on the new orientation and the redefinition of the objectives of language teaching and on the didactic models of the aesthetic reception of didactics of literature which requires putting the learner in intensive interaction with the text and motivating $\mathrm{him} /$ her to express himself/herself on his/her reading experiences. 


\section{SECOND SECTION - ENGLISH}

Krakue, S. P.'s paper titled, “Quod erat demonstrandum: A comparative study of narrative technique in Ama Ata Aidoo's Changes and Albert Camus' Les justes (The Just Ones)", demonstrates through textual analysis, how in Ama Ata Aidoo's Changes and Albert Camus Les justes, the authors resort to a specific form of irony to bring the discussion of issues raised to a conclusion. The technique consists in demonstrating clearly a huge discrepancy between a "fine" idea and its practical usefulness. Both authors successfully use narrative technique. Albert Camus demonstrates the hollowness of the idea of fighting for justice through revolutionary violence and Ama Ata Aidoo similarly demonstrates the fatuousness of the theory of women-emancipation-through-polygamy.

Adjandeh, E. A. analyses selected reports in Ghanaian media in relation to the clergy and identifies how Wole Soyinka's theme is reflected in these media in her paper titled, "Analysis of Wole Soyinka's Trials of Brother Jero in Relation to Ghanaian Religious Discourse". The study seeks to examine the extent to which themes in Soyinka's Trials of brother Jero play out in religious discourses in Ghana. The global nature of the issues problematized by Wole Soyinka also comes out through this study as the work set in Nigeria is analyzed in relation to the selected articles set in Ghana. The paper relies on a content analysis of Trials of Brother Jero and similar themes presented in the selected articles, and makes a few recommendations on how these religious issues could be partially, if not wholly, resolved in Ghana.

Sam, C. A.'s paper, "Decolonizing the Postcolony: Of Men, Spatial Politics and the New Nation in WA Thiongo's Wizard of the Crow", examines how Ngugi Wa Thiongo's Wizard of the Crow blatantly explores Africa's complicity in a seemingly cyclic colonization in the $21^{\text {st }}$ century and its attendant consequences for the total liberation of Postcolonial Africa. The study examines the correlation between masculine representations, spatial reorganization and futurity as alternative ways in thinking about Africa's future through Bakhtin's theory of the carnival and other such concepts as polyphony and the grotesque. The result of the analysis is that the correlation between forms of communities and forms of masculinities is an indication of a vision of hope for Postcolonial Africa. 
Kambou, M. K. \& Traore, S. A. in "Manipulation and the popular uprising in Burkina Faso in 2014", analyse the different discourses in the build-up to the popular uprising in Burkina Faso on the $30^{\text {th }}$ and $31^{\text {st }}$ October 2014. It attempts to clarify how political and civil society leaders use language and other non-linguistic elements to influence the ordinary citizens' minds and, indirectly, their actions. The analysis is premised on Van Dijk's (2006) Sociocognitive approach. The paper analyses the cognitive, the social and the discursive dimensions of manipulation in six political speeches (two speeches from Civil Society, two from the ruling party and two from the political opposition). The results suggest that the three groups manipulated their audiences, and finally, the ruling party lost following the resignation of the then Head of State, making way for a Transition government to take over the reins of governance.

De-Souza, A. Y. M.'s paper “'Test-taking Strategies of University of Cape Coast Students of French as a Foreign Language: a Case Study.” seeks to provide a description of test-taking strategies that may inform teaching and learning of French for better output in tests against the background that Ghanaian students of French as a foreign language deploy strategies that are not adequate enough in answering test items in French. The study examines data gathered right after a French test by level 200 students, using recollective verbalization protocols.

Kambou, M. K. \& Soma, L. examine in their paper titled, "Local Culture and EFL Vocabulary Learning”, the influence of learners' culture on foreign language vocabulary. The paper seeks to demonstrate that there is a link between culture and lexico-semantic errors committed by learners of English as a foreign language among Dioula speaking students in Burkina Faso. A language test composed of two written activities was used as the data collection instrument. The results revealed that the Dioula speakers' English is influenced by their culture. These results have some pedagogical implications. They, therefore, suggest that we adapt the teaching of EFL vocabulary to learners' culture.

Kabore, A. \& Nazortin, C. in "Critical Analysis of the Place and Importance of Literature in the Teaching / Learning of English and in School Leaving Certificate Examination in Burkina Faso from 1985 to 2018", analyse the types of texts given at the "Baccalaureate A" written examination in the last thirty years. In this study, quantitative and qualitative 
data are collected. Baccalaureate written English papers are the main focus of our collection. Teachers and supervisors are interviewed. The study is grounded on "Reader-Response Theory" which stresses the interactions between the reader and the text. The results of the study show that the great majority of texts proposed for "Baccalaureate A" examination, in the last thirty years, are non-literary texts.

Malgoubri, I., Sawadogo, M. \& Kambou, M. K.’s paper titled, “Digital Audio-visuals Aids and Listening in English as a Foreign Language Classrooms", is an experimental study which investigates the potential of digital audio-visuals to improve the listening skills of EFL learners in secondary schools in Burkina Faso. On the assumption that learners born around the year 2000 are digital natives, the researchers try integrating smartphone-friendly audio-visuals in their EFL classrooms in a four-week experiment involving one Experimental Group and one Control Group. The experiment aims at gauging the effectiveness of those aids operated via students' smartphones in improving learners' listening and speaking skills. Independent T-tests were used to compare the groups and Sample Paired TTests to make comparisons within groups. The study suggests that, if appropriately used, smartphones are excellent devices for language teachers and learners in this digitizing world.

Osei, R. N. \& Inusah, H.'s paper, “A Critique of the Images of Heaven in the Scriptures of the Abrahamic Religions: An Existentialist Perspective." Critically examines the scriptural images of heaven as captured in the Abrahamic religions - Judaism, Christianity and Islam - from the existentialist perspective. The paper argues that the idea of life beyond this earthly existence for all human beings in a specially prepared location by God for eternal happiness for those who obey His commands on earth called Heaven, as propounded by the Abrahamic Religions, throws up a lot of problems, especially from the existentialist perspective. The study concludes that the scriptures' constructs of heaven appear self-contradictory and fail to strike a chord with the contemporary image of the ideal society when perused from the existentialist perspective and should, therefore, be discarded.

Negedu, A. K.'s paper "Lexical Gaps and Ideological Shift in the Translation of Chinua Achebe's Things Fall Apart as "Le Monde S'effondre" in French." examines the ideological divergence between the title of the original text and the title of the translation, following an observation 
that in translating Chinua Achebe's Things Fall Apart, Michel Ligny translates directly Igbo terminologies, realities and beliefs into the French language. The paper concludes that the ideology that the translated title projects to French-readers is totally different from the ideology that the original title projects to English-readers.

Talburt, T., in "Political Transformation and Development in Africa: Lessons from Achebe's Things Fall Apart", formulates critical perspectives on the significance of Achebe's novel for the socio-political and economic transformation and development of the African continent. The paper challenges one of the central assumptions in this story that Africa falls apart as soon as it comes in contact with Europe. It questions aspects of political conservatism exhibited in Okonkwo who is suspicious of fundamental changes to his society. The discussion is based on the jollof rice principle of political hybridisation of development which proposes the amalgamation of Westernised and non-Western ideas and systems, in order to achieve economic development, rather than totally rejecting Westernisation in its entirety. The study uses examples of Western-style democracy and State intervention in Africa to demonstrate the significance of embracing some aspects of Westernisation through political hybridisation. 




\title{
Christ haïtien: Gouverneurs de la rosée et La Bible
}

\author{
Sylvester Petrus Krakue \\ University of Cape Coast, Cape Coast, Ghana.
}

\begin{abstract}
Consciemment ou non, les écrivains s'inspirent les uns des autres. Tel écrivain se tourne vers telle œuvre du passé pour en faire l'aliment de sa réflexion, tel autre y puise les matériaux de sa création. Gérard GENETTE a étudié les façons dont un texte peut entrer en relation avec d'autres textes et dans Palimpsestes, Gérard Genette explique que si la transtextualité désigne toutes les relations qu'un texte peut avoir avec d'autres textes, l'intertextualité est précisément la présence d'un texte dans un autre sous forme généralement implicite de citation, d'allusion ou de plagiat. A lire Gouverneurs de la rosée de Jacques Roumain, on est vite frappé par la présence d'idées, de motifs et d'énoncés bibliques dans le roman. Cette brève étude tâche d'interroger le roman pour élucider l'usage que le romancier a fait du texte biblique dans son activité créatrice. Il s'avère finalement que Jacques Roumain a emprunté des idées bibliques non seulement pour élaborer son intrigue mais aussi pour concevoir son personnage principal.
\end{abstract}

Mots-clés: création littéraire; dialogisme; intertextualité; ouverture du texte; transtextualité; structuralisme.

\section{Introduction}

Depuis les travaux fondateurs de Mikhail M. Bakhtine, théoricien soviétique, à partir de l'étude de Rabelais, on sait que le roman mélange nombre de discours, sociaux et littéraire, hétérogènes et contradictoires. Le roman, selon Mikhail M. Bakhtine est dialogique dans la mesure où il est le théâtre d'une multiplicité de voix, d'un dialogue incessant entre les discours et les textes. Le dialogisme d'après Bakhtine désigne tout énoncé où se 
confondent deux voix, qui se superposent. Bakhtine souligne, en effet, que : «[...] le langage est une opinion multilingue sur le monde [...] chaque mot renvoie à un contexte ou à plusieurs, dans lesquels il a vécu son existence socialement sous-tendue. »

Roland Barthes, prolongeant les travaux de Bakhtine a aussi écrit :

Tout texte est un intertexte, d'autres textes sont présents en lui, a des niveaux variables, sous des formes plus ou moins reconnaissables : les textes de la culture antérieure et ceux de la culture environnante; tout texte est un tissu nouveau de citations révolues (Barthes, 1997 : 816 - 817)

Pour notre part, nous avons été frappés par la présence dans Gouverneurs de la rosée d'idées, de motifs, d'énoncés bibliques et il nous a donc paru intéressant de l'interroger pour élucider l'usage que le romancier a fait de la Bible dans son activité créatrice. C'est-à-dire que ce qui nous concerne ici est l'intertextualité qui est la présence d'un texte dans un autre sous forme, généralement implicite de citation, d'allusion ou de plagiat.

Nous notons tout d'abord que dans Gouverneurs de la rosée, l'auteur a voulu structurer l'œuvre autour du thème de la rédemption. C'est-à-dire que le romancier a mis en place une intrigue qui permet de passer de la mort à la vie, voire la résurrection; de la perdition au salut. Voilà pourquoi nous lisons au début de l'œuvre : «On était déjà mort dans cette poussière, cette cendre tiède qui recouvrait ce qui autrefois avait été la vie.» (p. 22) Et à la fin de l'ouvrage : « Non, dit Annaïse [...] non, il n'est pas mort. Elle prit la main de la vieille et la pressa doucement contre son ventre où remuait la vie nouvelle.» (p. 192). Comme on le sait déjà la rédemption de l'homme est le grand super-thème qui traverse la Bible depuis le début, la Genèse, jusqu'à la fin, l'Apocalypse. Dans la Bible, nous lisons au début:

$[\ldots]$ le jour où tu en mangeras (de l'arbre de la connaissance du bien et du mal), tu mourras. (Genèse $2: 17)$

$[\ldots]$ tu es poussière, et tu retourneras à la poussière.

(Genèse 3 : 19)

Et à la fin: «[...] que celui qui a soif, vienne; que celui qui veut, prenne de l'eau de la vie gratuitement! (Apocalypse 22 :17). Ainsi, et la Bible et Gouverneurs de la rosée débutent avec la menace de la mort: 
«Nous mourrons tous... [...] la vieille Délira Délivrance dit: nous mourrons tous : $[\ldots] »($ p. 11)

Et tous les deux textes se terminent sur une promesse de vie. De plus, les deux textes commencent avec la poussière de la terre: «L'Eternel Dieu forma l'homme de la poussière du sol. (Genèse 2:7) pour se terminer avec l'élément aquatique.

Gouverneurs de la rosée à maintes reprises associe étroitement mort et poussière. On peut dire en effet que le roman symbolise la mort par la poussière comme le montrent ces passages : «Dorisca et Sauveur sont déjà cendre et poussière, ça fait des années qu'ils reposent en paix ; le temps passe, la vie continue. » (p. 125)

$[\ldots]$ nous enterrons aujourd'hui notre nègre et il s'en va vers la tombe. Il s'en va vers la poussière. (p. 159)

Ma force se dessèche comme l'argile, Et ma langue s'attache à mon palais ; Tu me réduis à la poussière de la mort (Psaume $22: 16)$

Le psalmiste observe aussi que tout être vivant est absolument dépendant de Dieu et l'exprime ainsi: "Tu caches ta face: ils sont épouvantés; tu leur retires le souffle: ils expirent et retournent dans leur poussière.»(Psaume $104: 29)$

Il est évident que Jacques Roumain a trouvé cette association entre mort et poussière si utile pour son propos qu'il l'a exploitée en métaphorisant la poussière pour signifier la mort au début de Gouverneurs de la rosée. Par ailleurs, la sècheresse dans la Bible est souvent regardée comme une malédiction envoyée par Dieu pour punir les hommes de leurs fautes. De tels passages comme 1 Rois 17 et Deutéronome 28 témoignent du statut de la sècheresse comme une malédiction indiquant la défaveur de Dieu envers son peuple :

Mais si tu n'obéis pas à la voix de l’Éternel, ton Dieu, [...], voici toutes les malédictions qui viendront sur toi et qui t'atteindront:

$[\ldots]$

Le ciel sur la tête sera de bronze, et la terre sous toi sera de fer. L'Eternel enverra pour pluie à ton pays de la poussière et de la poudre ; [...] Deutéronome $28: 15,23,24$. 
Gouverneurs de la rosée fait écho à cette perspective biblique lorsqu'en désespoir de cause, Bienaimé dit : «Une saison malédictionée comme celle-là, je n’en ai jamais vu de pareille. » (p. 99).

Ou lorsque Délira Délivrance demande: «Du levant au couchant, il n'y a pas un seul grain de pluie dans tout le ciel : alors est-ce que le bon Dieu nous a abandonnés? ? (p. 36)

Tout comme le thème de la rédemption se tisse autour du Christ, l'intrigue dans Gouverneurs de la rosée s'articule autour d'un groupe de personnages qu'on peut assimiler à la sainte Famille dans la Bible, c'est-à-dire le Christ, son père adoptive, Joseph, et sa mère la Vierge Marie. Seulement, l'auteur, pour mettre encore de l'accent sur le thème de la rédemption, donne aux membres de «la Sainte famille » dans le roman des noms qui rappellent et renforcent tous le thème du salut.

Ainsi, le héros du roman porte le nom de Manuel qui peut être identifié à Emmanuel, autre nom du Messie qui signifie «Dieu est avec nous » (et on sous-entend : pour nous sauver) (Matthieu 1:23). Délira Délivrance - le nom de la mère du héros - est encore un nom qui fait écho au thème du salut ou de l'émancipation. Quant au nom du père de Manuel, Bienaimé, nous voyons là encore une référence au Christ puisqu'il est dit dans la Bible que lors du baptême du Christ, «Au moment où il sortait de l'eau, [...] une voix se fit entendre des cieux: Tu es mon Fils bien-aimé, objet de mon affection.» (L'Évangile selon Marc au chapitre premier et aux versets 11, 12). Même le nom de l'amante du héros, Annaïse, fait peut-être allusion au thème de la rédemption dans la mesure où « résurrection» en grec est «anastasis » - - Ainsi, il nous paraît significatif que ce soit Annaïse qui porte en elle la «vie nouvelle » la preuve, selon elle, que Manuel n'est pas mort. Pour ainsi dire, grâce à celle dont le nom signifie " résurrection », le héros va renaitre ou, si l'on préfère, va être ressuscité.

Nous remarquons un autre cas d'emprunt à la Bible lorsque Le Simidor défend qu'on l'appelle par ce nom-là.

- Ah, simidor, simidor, disait le vieux, quelle est cette misère?

Le Simidor secouait la tête $[\ldots]$

- Ne m'appelle pas simidor. Appelle-moi Antoine : c'est mon nom. Vois-tu, compère, quand tu dis : simidor, ça me fait songer au temps longtemps. C'est amer ces souvenances-là, c'est amer comme le fiel (p. 68). 
Dans le passage, le Simidor proteste l'emploi du «Simidor» au nom d'un regretté passé. L'intéressant ici, c'est que dans la Bible, dans des circonstances pareilles de sécheresse, un personnage défend l'emploi d'un nom en raison d'un regretté passé: ce personnage aussi parle d'«amertume» comme le montre ce passage de Ruth au chapitre premier.

Elles marchèrent toutes deux jusqu'à leur entrée à Bethléhem. Lorsqu'elles entrèrent à Bethléhem, toute la ville fut étonnée à leur sujet et les femmes disaient : Est-ce là Noémie ?

Elle leur dit: Ne m'appelez pas Noémie ; appelez-moi Mara, car le Tout-Puissant m'a rendu la vie bien amère!

Comblée j'étais partie ; vide l'Éternel me ramène [...] (Ruth 1 : 19 - 21).

De même, lorsque Manuel avoue: "Sans la concorde la vie pas de goût, la vie n'a pas de sens...» (p. 126).

On ne peut s'empêcher de penser que l'auteur fait allusion au livre des Psaumes où il est écrit au cent trente-troisième chapitre :

Voici qu'il est bon, qu'il est agréable pour des frères d'habiter unis ensemble!

C'est comme l'huile la meilleure [...] C'est comme la rosée de l'Hermon. [...] Car c'est là que l'Eternel donne la bénédiction, la vie, pour l'éternité. (Psaume 133:1 - 3)

En ce qui concerne le rôle de Gervilain Gervilis dans Gouverneurs de la rosée, une première remarque s'impose : pour qui parle un peu l'anglais, le nom se prononce presque comme «the devil» («le diable» en anglais). L'auteur, de propos délibéré, a choisi un nom qui suggère que le personnage est à la fois «vil» et «vilain». D'ailleurs, l'auteur, par une référence directe à la Bible appelle ce personnage «le malveillant», "Judas» (p. 92). On se rappelle que Judas, c'est celui qui a trahi le Christ de la Bible (Marc 14:10 - 11). En effet, l'auteur fait une allusion intéressante au texte biblique lorsque le narrateur raconte qu'au cours d'une réunion qui se déroulait chez le vieux Larivoire, Gervilain menaça Manuel « et il disparut dans la nuit ». (p.153)

Ce passage est une allusion directe à l'Evangile de Jean, où il est écrit qu'au cours d'une réunion,

Judas prit le morceau et sortit aussitôt. Il faisait la nuit ». (Jean $13: 30$ ) Les traitres préfèrent agir à la faveur de la nuit, et tout comme le Judas biblique livra Jésus, le Christ, aux principaux sacrificateurs pour être sacrifié, Gervilain assassina Manuel cette nuit même où il disparut dans la nuit. "Un bruit 
d'herbe froissée le fit se retourner. Il n'eut pas le temps de parer le coup. L'ombre dansa devant lui et le frappa encore. Un goût de sang lui monta à la bouche. Il chancela et s'affaissa. La torche s'éteignit. » (p. 155).

On voit dans ce style particulièrement sec que l'auteur associe Gervilain et la mort avec l'obscurité (l'ombre dansa...la torche s'éteignit), mais Manuel avec la lumière. C'est ce que fait aussi le texte biblique : la mort du Christ a provoqué l'obscurité en plein midi : selon l'évangile de Luc au vingttroisième chapitre, nous lisons : «Il était déjà la sixième heure environ (c'est-àdire environ midi), et il y eut des ténèbres sur toute la terre, jusqu'à la neuvième heure (quinze heures). Le soleil s'obscurcit, [...]. » Luc 23 : 44-45.

Manuel, sur son lit de mort, énonce ce que nous appellerons ici le principe de la réconciliation par le sang, qui n'est finalement autre que le thème de la rédemption :
Vous avez offert les sacrifices aux Loa, vous avez offert le sang des poules et des cabris pour faire tomber la pluie, ça n'a servi à rien. Parce que ce qui compte, c'est le sacrifice de l'homme. C'est le sang du nègre. Va trouver Larivoire. Dis-lui la volonté du sang qui a coulé: la réconciliation pour que la vie recommence, $[\ldots]$ (p. 160)

Dans ce passage, Manuel mettait l'accent sur la nécessité absolue de la réconciliation. C'est grâce à la réconciliation qu'un recommencement de la vie sera possible. Or la réconciliation n'est possible (selon Manuel) qu'à condition de l'effusion du sang d'un nègre. Voilà qui explique aussi pourquoi le sang des poules et des cabris n'a pas été efficace : on visait à faire tomber la pluie sans passer d'abord par la réconciliation. Voilà pourquoi le sang du nègre est un meilleur sang, un meilleur sacrifice.

Cette idée de réconciliation par le sang, réconciliation pour que la vie recommence, est éminemment biblique. Tout d'abord, selon l'Ancien Testament, c'est Dieu lui-même qui aura recommandé de rechercher le pardon et la réconciliation en recourant au sang de l'animal. Dieu aura donné aussi la raison : «Car la vie de la chaire est dans le sang. Je vous l'ai donné sur l'autel afin qu'il serve d'expiation pour votre vie, car c'est le sang qui fait expiation pour la vie.» (Lévitique $17: 11$ ). Et c'est ainsi que le peuple Israelite en est venu à offrir des sacrifices de sang des animaux. Pourtant dans le Nouveau Testament, le Christ, comme Manuel dans Gouverneurs de la rosée, a dû expliquer que l'ancien système de rechercher le pardon avait fait son temps.

Dans la lettre aux Hébreux, la Bible explique: « Mais par ces sacrifices, on rappelle chaque année le souvenir des péchés. Car il est impossible que le sang des taureaux et des boucs ôte les péchés. » (Hébreux $10: 3$-4). Puisque le 
sang des animaux ne pouvait ôter les péchés, il fallait un meilleur sang, qui, cette fois-ci, a coulé depuis les veines du Christ. L’Apôtre Paul explique donc : « En [lui (le Christ)] nous avons la rédemption, le pardon des péchés [...] Car il a plu à Dieu de tout réconcilier avec lui-même, [...] en faisant la paix par lui, par le sang de sa croix. » (Colossiens 1: 14, 16, 19, 20). Ainsi, on voit que Manuel, en acceptant de mourir et en renonçant à la vengeance, a permis que la vie recommence à Fonds-Rouge parce que l'eau a été sauvée grâce à la réconciliation. De même, le Christ biblique en donnant son sang, sa vie, a réconcilié les croyants à leur Dieu et a permis qu'une nouvelle vie recommence entre le croyant et son Dieu.

Il faudra maintenant tourner l'attention à l'idée que le Christ restera toujours le guide vivant de son peuple. Dans la Bible il est dit que le Christ, avant de monter au ciel, a donné cette assurance à son peuple :

[...] voici, je suis avec vous tous les jours, jusqu’à la fin du monde. (Matthieu $28: 20$ )

Et l'Évangéliste Marc, témoigne, en effet :

Et ils (les disciples) s'en allèrent prêcher partout. Le Seigneur travaillait avec eux et confirmait la parole par les signes qui les accompagnaient. (Marc $16: 20$ )

J. ROUMAIN fait allusion à cette idée de la présence perpétuelle du Christ lorsqu'il écrit : " Il est mort, Manuel, mais c'est toujours lui qui guide. » (p. 189). Ainsi, nous voyons que ROUMAIN s'est tourné vers la Bible pour emprunter certaines idées non seulement pour élaborer son intrigue mais aussi pour concevoir son personnage principal.

\section{Conclusion}

Pour conclure, nous disons simplement qu'en matière de création littéraire, emprunter ses matériaux ne peut pas être un vice pourvu qu'on sache mettre à profit les ressources empruntées.

\section{Notes}

1. Bakhtine, Mikhail. (1978). Esthétique et Théorie du roman. Paris : Gallimard. p. 114

2. Barthes, Roland. (Théorie du) Texte in Dictionnaire des genres et notions littéraires, cité dans Adam, J. M. «Textualité et 
Transtextualité d'un conte d'Anderson » in POETIQUE (2001, No 128) p. 421.

\section{Références}

Bakhtine M. (1978). Esthétique et Théorie du roman. Paris : Gallimard. p.114

Barthes, Roland. (Théorie du) Texte in Dictionnaire des genres et notions littéraires, cité dans Adam, J.M «Textualité et Transtextualité d'un conte d'Anderson » in POETIQUE (2001, No 128) p.421.

La Bible, Traduction du Docteur Louis Segond. Alliance Biblique Universelle, 1910.

Roumain, J. (1946). Gouverneurs de la rosée, Paris: Les Editeurs Réunis. 
